\title{
A review of the occurrence of hemoplasmas (hemotrophic mycoplasmas) in Brazil
}

\author{
Uma revisão da ocorrência dos hemoplasmas (micoplasmas hemotróficos) no Brasil
}

\begin{abstract}
Alexander Welker Biondo ${ }^{1,8 *}$; Andrea Pires dos Santos ${ }^{2}$; Ana Marcia Sá Guimarães ${ }^{2,9}$; Rafael Felipe da Costa Vieira ${ }^{1,3}$; Odilon Vidotto ${ }^{3}$; Daniel de Barros Macieira ${ }^{4}$; Nádia Regina Pereira Almosny ${ }^{4}$; Marcelo Beltrão Molento ${ }^{1}$;

Jorge Timenetsky ${ }^{5}$ Helio Autran de Morais ${ }^{6}$; Félix Hilário Diáz González; Joanne Belle Messick $^{2}$
\end{abstract}

${ }^{1}$ Departamento de Medicina Veterinária, Universidade Federal do Paraná - UFPR

${ }^{2}$ Department of Veterinary Pathobiology, Purdue University

${ }^{3}$ Departamento de Medicina Veterinária Preventiva, Universidade Estadual de Londrina - UEL

${ }^{4}$ Departamento de Patologia Clínica Veterinária, Universidade Federal Fluminense - UFF

${ }^{5}$ Departamento de Microbiologia, Universidade de São Paulo - USP

${ }^{6}$ Department of Clinical Sciences, Oregon State University

${ }^{7}$ Departamento de Patologia Clínica Veterinária, Universidade Federal do Rio Grande do Sul - UFRGS

${ }^{8}$ Department of Veterinary Pathobiology, University of Illinois

${ }^{9} \mathrm{CAPES}$ - Fulbright Program

Received January 14, 2009

Accepted April 16, 2009

\begin{abstract}
Recent studies have been conducted in Brazil using molecular techniques for the detection of hemotrophic mycoplasmas in several mammals. In domestic cats, Mycoplasma haemofelis, 'Candidatus M. haemominutum', and 'Candidatus M. turicensis' infections have been identified. These species have also been found in free-ranging and captive neotropical felid species. Two canine hemoplasmas, Mycoplasma haemocanis and 'Candidatus Mycoplasma haematoparvum', have been identified in dogs. In commercial swine populations, Mycoplasma suis was found to be highly prevalent, especially in sows. Moreover, novel mycoplasma species have been identified in Brazilian commercial pigs and domestic dogs. A hemoplasma infection in a human patient infected with the human immunodeficiency virus (HIV) was also recently documented. In conclusion, hemoplasma species are common and important infectious agents in Brazil. Further studies should be conducted to better understand their impact on pets, production animals, and wildlife fauna, as well as their role as zoonotic agents, particularly in immunocompromised patients.
\end{abstract}

Keywords: Hemoplasma, Mycoplasma haemofelis, Mycoplasma suis, HIV.

\section{Resumo}

Estudos recentes utilizando técnicas moleculares para a detecção de micoplasmas hemotróficos em diferentes mamíferos têm sido conduzidos no Brasil. Em gatos domésticos, infecçóes por Mycoplasma haemofelis, 'Candidatus M. haemominutum' e 'Candidatus M. turicensis' foram identificadas. Estas espécies também foram encontradas em felídeos neotropicais de vida livre e de cativeiro. Dois hemoplasmas caninos, Mycoplasma haemocanis e 'Candidatus Mycoplasma haematoparvum', foram identificados em cães domésticos. Em populaçôes comerciais de suínos, Mycoplasma suis possui alta prevalência, especialmente em porcas. Além disso, novas espécies de hemoplasmas foram detectadas em suínos comercias e cães. Infecção por um hemoplasma em um paciente humano infectado com o vírus da imunodeficiência humana (HIV) foi recentemente documentada. Em conclusão, espécies de hemoplasmas são comuns e importantes agentes de infecções no Brasil. Estudos futuros devem ser conduzidos para melhor entender seu impacto em cáes e gatos, animais de produção e na fauna silvestre, e também para determinar o seu papel como agentes zoonóticos, particularmente em pacientes imunocomprometidos.

Palavras-chave: Hemoplasma, Mycoplasma haemofelis, Mycoplasma suis, HIV.

\footnotetext{
*Corresponding author: Alexander Welker Biondo

Departamento de Medicina Veterinária, Universidade Federal do Paraná - UFPR

Rua dos Funcionários 1540, CEP 80035-050 Juveve, Curitiba - PR, Brazil

Phone: +55 (41) 3350-5723 / 3350-5623; e-mail: abiondo@illinois.edu
} 


\section{Introduction}

Hemoplasmas (hemotrophic mycoplasmas) are obligate erythrocyte bacteria that infect a wide range of mammalian species and may induce anemia in an infected host. Initially, hemoplasmas were classified in the order Rickettsiales based on morphology and response to antibiotic therapy (WEISS; MOULDER, 1984). However, molecular studies based on the 16S rRNA gene have shown that the genera Haemobartonella and Eperythrozoon are more closely related to the pneumoniae group of mycoplasmas, leading to the reclassification within the genus Mycoplasma (RIKIHISA et al., 1997; NEIMARK et al., 2001). Mycoplasmas are characterized by the absence of cell wall and diminutive genome that gives strict dependence to the host cell. Accordingly, hemoplasmas range from 0.3 to $1 \mu \mathrm{m}$ in diameter and can be found in form of cocci, rings, or rods attached to and forming indentations on the surface of red blood cells (MESSICK et al., 2004). In contrast to several mucosal mycoplasmas, these organisms have never been grown successfully in culture.

Species of hemoplasmas (i.e., Mycoplasma haemofelis) have been described in all continents, except Antarctica, and it is thus believed that these organisms have a worldwide distribution. Their main form of transmission is probably through blood-sucking arthropods; there appears to be a high prevalence of hemotrophic mycoplasmas in tropical regions, likely due to environmental conditions favoring transmission of these organisms by vectorborne agents (MACIEIRA, 2008). Nevertheless, studies related to hemoplasma transmission are scarce and mostly not conclusive. Since hemoplasmas cannot be cultured in vitro, the dose of organisms in experimental infections cannot be accurately measured and interferes with the results. Experimental studies suggest fleas (Ctenocephalides felis) as responsible for the transmission of $M$. haemofelis and 'Candidatus M. haemominutum' in cats (WOODS et al., 2005), the tick Rhipicephalus sanguineus as the main vector of $M$. haemocanis in dogs (SENEVIRATNA et al., 1973), the lice Polyplax serrata and P. spinulosa as vectors for $M$. coccoides transmission in mice (BERKENKAMP; WESCOTT, 1988), and Stomoxys calcitrans and Aedes aegypti as vectors of M. suis in pigs (PRULLAGE et al., 1993).

Animal hemoplasmosis ranges from a severe anemia to a chronic infection without clinical signs. Acutely infected animals may present a mild to life-threatening hemolytic anemia in addition to anorexia, fever, icterus, and hypoglycemia, depending on the hemoplasma species involved. The chronic form has been commonly associated with the absence of clinical signs; however, the long-term consequences of hemoplasma infection in animals are still unclear. Chronically infected animals may become anemic following immunossupression events, and growth retardation in feeder pigs and poor reproductive performance in sows have been described (HOELZLE, 2008). In addition, hemoplasmas vary in pathogenicity and virulence; species-specific identification should always be conducted when performing the diagnosis (MESSICK, 2004).

Diagnosis of the infection has historically relied on the evaluation of Romanowsky stained blood smears. Hemoplasmas are mostly found attached to the erythrocytes; some organisms may also be found in the plasma because of detachment from the cells. Due to cyclic parasitemia and chronic infection, this technique is neither sensitive nor specific for infection diagnosis. Consequently, molecular diagnostic techniques, such as standard and real-time PCR, have been extensively and successfully used to identify acute and chronically infected animals (MESSICK, 2004; HOELZLE, 2008).

Over the last few years, there has been a growing interest in hemoplasma infection of domestic and wild animals in Brazil. Acute and life-threatening cases of the disease have been observed in domestic pigs and cats (unpublished data). Additionally, new hemoplasma species have been described in pigs (MESSICK et al., 2007) and dogs (SANTOS, 2008). Our goal in this review is to summarize all recent molecular studies that characterize the occurrence of hemoplasmas in Brazil (Table 1, Figure 1).

\section{Companion Animals}

Although hemoplasmas have been frequently found on blood smears of cats in Brazil, molecular approaches for detecting hemotrophic mycoplasma species have increased the detection sensitivity in anemic and non-anemic cats from different regions of the country. The three currently known species of feline hemoplasmas ( $M$. haemofelis, 'Candidatus M. haemominutum', and 'Candidatus M. turicensis') have been molecularly detected in Brazilian domestic and wild cats (DE MORAIS et al., 2007; SANTOS, 2008; WILLI et al., 2007).

Using PCR, 14 of 37 (38\%) anemic cats [packed cell volume (PCV) $<24 \%$ ] from a Curitiba veterinary hospital harbored M. haemofelis, 4 (11\%) were positive for 'Candidatus M. haemominutum', and 3 (8\%) were co-infected with both organisms (BAUMANN et al., 2006). Blood smear evaluations in this study were not reliable for hemoplasma diagnosis. Mycoplasma-like bodies were found in only about $1 / 3$ of PCR positive samples (SANTOS, 2008).

In Porto Alegre, 371 cats were tested by PCR for the three feline hemoplasmas; $21.3 \%$ were infected by at least one species. The most prevalent species in this study was 'Candidatus M. haemominutum' with 50 positive cats $(13.5 \%)$, whereas 'Candidatus M. turicensis' and $M$. haemofelis were found in $10(2.7 \%)$ and $8(2.2 \%)$ cats, respectively (SANTOS, 2008). Male cats and cats with outdoor access were more likely to be infected with hemoplasmas in this study. This was also the first report of 'Candidatus M. turicensis' in domestic cats in Brazil.

In a study at the Small Animal Hospital, University of São Paulo, Southeast Brazil, M. haemofelis and 'Candidatus M. turicensis' were detected by PCR and confirmed by $16 \mathrm{~S}$ rRNA gene sequencing in $23(8.5 \%)$ and $1(0.37 \%)$ out of 270 anemic cats (PCV < 30\%), respectively (HORA, 2008). Another survey compared 80 healthy and 74 sick cats from Botucatu, São Paulo State; 8 (10\%) healthy cats and $15(20 \%)$ of the symptomatic cats were positive for M. haemofelis and/or 'Candidatus M. haemominutum' (BATISTA, 2004). Of the 23 positive samples, 11 had $M$. haemofelis, 4 had $M$. haemominutum, and 8 were co-infected with both organisms. Association between clinical signs and infection with $M$. haemofelis was observed, suggesting a higher virulence of $M$. haemofelis when 
Table 1. Hemotrophic mycoplasmas described in Brazil.

\begin{tabular}{|c|c|}
\hline Mycoplasmas & GenBank accession numbers* \\
\hline \multicolumn{2}{|l|}{ Cats } \\
\hline M. haemofelis & EU442616 to EU442640, FJ004275 \\
\hline 'Candidatus M. turicensis' & EU861063, EU580598, EU580599, EU442629 \\
\hline \multicolumn{2}{|l|}{ Dogs } \\
\hline M. haemocanis & N.A. \\
\hline Organism similar to 'Candidatus M. haemominutum' & AY297712 \\
\hline Organism similar to 'Candidatus M. turicensis' & FJ429283 \\
\hline \multicolumn{2}{|l|}{ Pigs } \\
\hline M. suis & N.A. \\
\hline Organism similar to 'Candidatus M. haemominutum' & N.A. \\
\hline Organism similar to $M$. coccoides & FJ667774, FJ667773 \\
\hline \multicolumn{2}{|l|}{ Laboratory animals } \\
\hline M. coccoides & N.A. \\
\hline \multicolumn{2}{|l|}{ Humans } \\
\hline Organism similar to $M$. haemofelis & EU888930 \\
\hline
\end{tabular}

*Accession numbers from Brazilian isolates of hemoplasmas (SANTOS, 2008). N.A.: not available in GenBank database.

compared to M. haemominutum. One hundred and forty-nine cats from Rio de Janeiro were also screened for hemoplasmas using PCR and Southern blot; 15 (10\%) were positive for 'Candidatus M. haemominutum', 6 (4\%) for $M$. haemofelis, and 3 (2\%) were co-infected with both hemoplasmas (MACIEIRA et al., 2006; MACIEIRA et al., 2008); eight positive samples were selected for sequencing of the $16 \mathrm{~S}$ rRNA gene and showed $100 \%$ identity to published sequences on the GenBank.

Hemoplasma frequency comparisons among different studies must be cautiously performed. Differences in animal population characteristics as well as diagnostic techniques are likely to influence the results. In addition, the fact that not all hemoplasmas are evaluated in every study further confounds the ability to compare these results. Nevertheless, the prevalence of cat hemoplasmas seems to vary between cities from Southern and Southeastern Brazil. Hemoplasma infection in anemic cats ranged from $8.5 \%$ in São Paulo to 38\% in Curitiba. Prevalence in samples including anemic and non-anemic cats showed an overall prevalence of $16 \%$ in Rio de Janeiro and $15 \%$ in Botucatu. Cats infected with feline immunodeficiency virus (FIV), either alone or in association with feline leukemia virus (FeLV), were at a higher risk of harboring 'Candidatus $\mathrm{M}$. haemominutum' than retroviral negative cats in studies in Rio de Janeiro and São Paulo (HORA, 2008; MACIEIRA et al., 2008). It can be concluded that hemoplasma infections are common in cats from Southern and Southeastern Brazil.

Dogs are known to be infected with at least two hemoplasmas, M. haemocanis and 'Candidatus M. haematoparvum'. Mycoplasma haemocanis was described in blood smears of dogs from Belo Horizonte, Southeast Brazil (O'DWYER et al.1997), and later characterized by PCR in four non-splenectomized dogs from a veterinary hospital in Londrina, South Brazil (DE MORAIS et al., 2003) as well as in other canine populations (SANTOS, 2008; TRAPP et al., 2006). Recently, a PCR survey was conducted in Belo Horizonte and the surroundings to compare infection rates for $M$. haemocanis between urban and rural areas. Twenty (11.3\%) of 176 dogs living in rural areas were positive, whereas 6 of 104 (5.8\%) dogs from urban areas harbored the organism. Although a survey with 78 healthy blood donors in São Paulo showed no positive sample for $M$. haemocanis, only blood smear evaluation was made and therefore results lack sensitivity (SANTOS, 2008).

A PCR survey for both $M$. haemocanis and 'Candidatus M. haematoparvum' was conducted in Londrina (SANTOS, 2008). A total of 147 dogs with at least one laboratory abnormality (leucopenia, thrombocytopenia, pancytopenia, or anemia) were tested, resulting in $2(1.4 \%)$ positive samples for $M$. haemocanis and 11 (7.5\%) for 'Candidatus M. haematoparvum'. However, the sequenced PCR amplicons of 'Candidatus M. haematoparvum' were only $85 \%$ similar to the 'Candidatus M. haematoparvum' described by Sykes et al. (2005), but showed $96 \%$ homology to M. haemofelis and $96 \%$ to M. haemocanis. Results suggested that, although amplified by a standard 'Candidatus M. haematoparvum' PCR protocol, this particular species of hemoplasma is phylogenetically closer to M. haemocanis than to 'Candidatus M. haematoparvum'. It is unknown if this organism is a new species of hemoplasma or a strain variation of $M$. haemocanis.

In addition, two other novel hemoplasmas have been identified by PCR in dogs from Brazil (SANTOS, 2008). A canine hemoplasma more similar to 'Candidatus M. haemominutum' (98\% identity to 


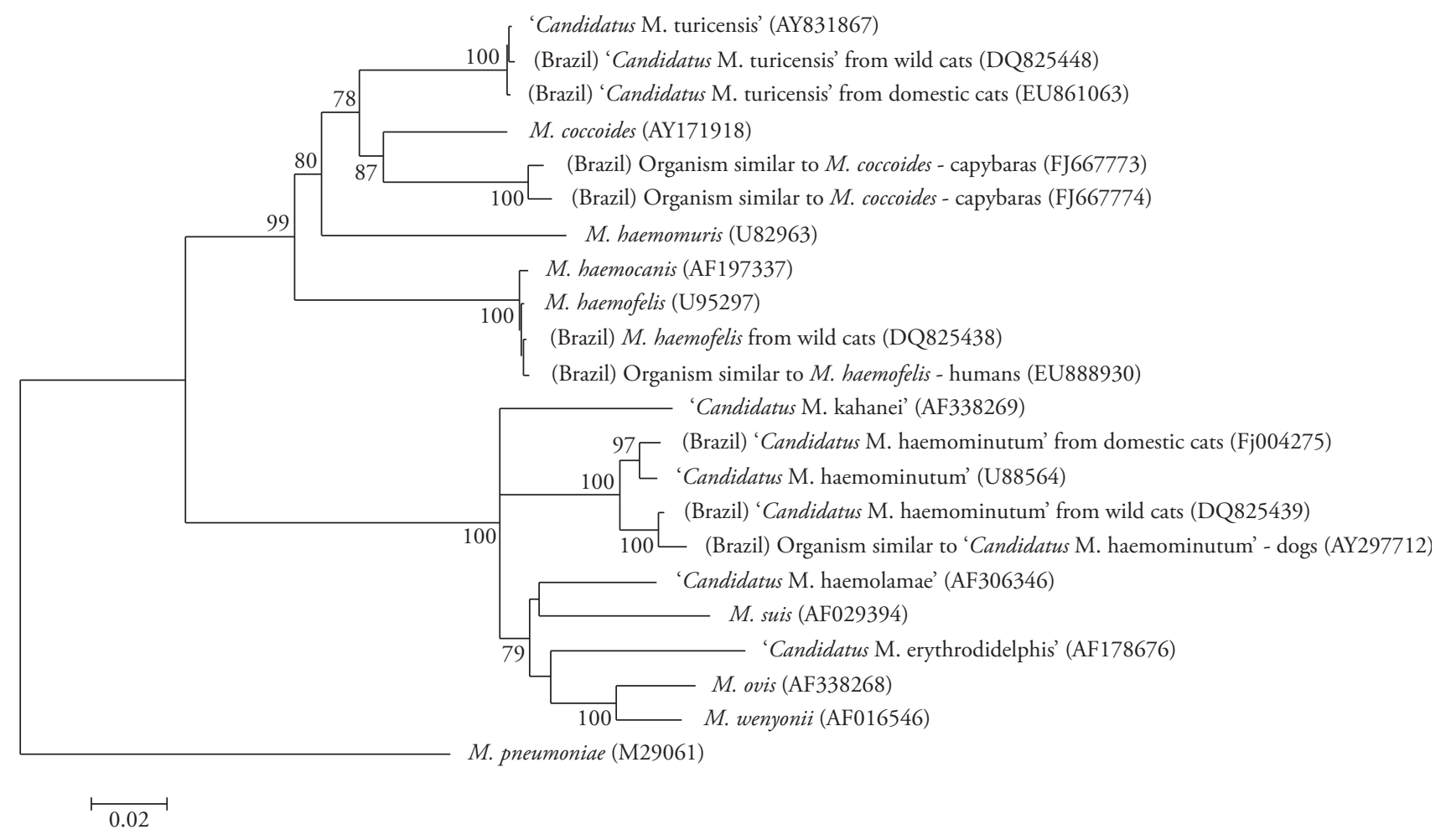

Figure 1. Phylogenetic tree of $16 \mathrm{~S}$ rRNA gene sequences of Brazilian hemoplasma isolates and other hemoplasma sequences held in the GenBank database. Analyses were performed using MEGA software version 4 (TAMURA et al., 2007). Briefly, selected sequences were aligned using the ClustalW tool and manually adjusted. The phylogenetic tree was constructed with the neighbor-joining method based on a distance matrix corrected for nucleotide substitutions by the Kimura two-parameter, and the data set was resampled 1000 times to generate bootstrap percentage values. Mycoplasma pneumoniae 16S rRNA gene sequence was used as outgroup. Bootstrap values $>70 \%$ are shown. Only sequences $>1100$ bp long were used.

16S rRNA gene sequence) than to 'Candidatus M. haematoparvum' was detected by PCR in a dog from Londrina and a novel hemoplasma with $98-100 \%$ identity with the 'Candidatus M. turicensis' found in cats was also amplified in 7 of 10 splenectomized dogs from Porto Alegre (SANTOS, 2008). Again, it is unclear if this is a new canine hemoplasma species or a demonstration that 'Candidatus M. turicensis' also can infect dogs.

\section{Production Animals}

Mycoplasma suis was surveyed by PCR and Southern blot in 186 pigs (121 sows, 61 piglets and 4 boars) from four farms in Southern Brazil, the region responsible for most of the pork production in the country. In this study, 22 sows (18.2\%) were positive by PCR, whereas $40(33.1 \%)$ were positive by Southern blot; 1 piglet (2\%) and 1 of 4 boars were also positive. Sequence of PCR products from 4 positive sow samples showed over $99 \%$ identity to the published $16 \mathrm{~S}$ rRNA gene sequence of $M$. suis (AF029394). There was no association between PCV and the infection, suggesting a subclinical or chronic form of the disease in pigs (GUIMARÃES et al., 2007a). Therefore, although acute infection and high mortality rates have declined due to the addition of tetracycline to the food, $M$. suis infection is still present in pig herds and may adversely affect weight gain and meat production. In addition, a novel mycoplasma species was detected in pigs from these farms (MESSICK et al., 2007); 14 (7.5\%) of 186 domestic pigs were PCR-positive for an organism with $98-99 \%$ identity to 'Candidatus M. haemominutum', some of them coinfected with M. suis. When first described in the 1950s, eperythrozoonosis was a disease known to have two distinct causative agents: E. parvum and E. suis. However, pigs infected with E. parvum showed mild clinical signs. This parasite has not yet been fully characterized, except for three reports more than 40 years ago and another description more than 25 years ago (NEIMARK et al., 2005). The novel species characterized in this study is likely to be the putative parasite E. parvum.

Hemoplasma species have not been described in Brazilian ruminants. $M$. wenyonii and $M$. ovis are the causative agents of hemoplasmosis in cattle and sheep, respectively (NEIMARK et al., 2001; NEIMARK et al., 2004). Recently, a proposed novel species was identified in cattle from Japan: 'Candidatus M. haemobos' (TAGAWA et al., 2008). Since most of the hemotrophic mycoplasmas have been reported in Brazilian domestic animals, hemoplasmas are likely to be present in ruminants. 


\section{Wildlife Animals}

The three species of feline hemoplasmas have been found in both free-ranging and captive wild-cat species (WILLI et al., 2007). In a study with 110 captive wild felids, including five non-native species, 11 were positive for 'Candidatus M. haemominutum' (1 lion, 1 geoffroy's cat, 1 margay, 4 ocelots, 3 oncillas, and 1 puma), 2 were positive for $M$. haemofelis ( 1 margay and 1 ocelot), and 1 was positive for 'Candidatus M. turicensis' (1 ocelot) by PCR; results were also confirmed by DNA sequencing (Table 1 ). In another study, a 12-year-old lion was PCR positive for 'Candidatus M. haemominutum' at the Zoological Garden of Curitiba, Southern Brazil (GUIMARÁES et al., 2007a). Recently, a total of 57 neotropical felids maintained in captivity at Foz do Iguaçu in Southern Brazil were tested for $M$. haemofelis and 'Candidatus M. haemominutum' infection by PCR. Only a 7-year-old margay showed a positive result for $M$. haemofelis. It is of particular interest that flea infestation is more common in São Paulo zoos (ADANIA et al., 1998) and uncommon in Refúgio Bela Vista at Foz do Iguaçu (GUIMARÁES, 2008). This may explain the differences in hemoplasma infection reported in these studies.

In Marana and Clara, Northeastern Brazil, another survey in 29 neotropical felids was conducted. Six ocelots and 1 jaguarundi were positive $(24.1 \%)$ by PCR. Three of them were co-infected with $M$. haemofelis and 'Candidatus M. haemominutum' (2 ocelots and 1 jaguarundi), and 4 with only 'Candidatus M. haemominutum' (SANTOS, 2008).

A search for parasites on blood smears in 374 small wild mammals, including nine rodent (Akodon montensis, A. serrensis, Delomys dorsalis, D. sublineatus, Nectomys squamypes, O1 ligorysomys nigripes, Oxymycterus sp., Thaptomys nigrita, and Trynomis dimediadus) and six marsupial (Didelphis aurita, Gracilynanus sp., Marmosops incanus, Monodelphis scallops, Philander frenata, Thylamis velutinus) species was undertaken in three areas of the Atlantic Forest in Southeastern Brazil (SILVA et al., 2007). A total of 65 specimens (17.4\%) belonging to nine different mammals (six rodents and three marsupials) were infected with hemotrophic mycoplasmas or Babesia sp. Packed cell volume and total plasma protein were similar between infected and non-infected specimens, suggesting that wild mammals may have a sub-clinical or chronic infection.

Recently, a novel hemoplasma species was detected in capybaras (Hydrochaeris hydrochaeris) (VIEIRA et al., 2009). A total of 10 captive and 21 free-ranging animals were surveyed by PCR for hemoplasma infection. $M$. coccoides and $M$. haemomuris were not molecularly detected in these animals; however, 17 (80.95\%) free-ranging and $3(30 \%)$ captive capybaras were positive for a not-yet-described hemoplasma species. Sequence analysis of the 16S rRNA gene shows that this isolate is closely related to M. coccoides, but with only $92 \%$ identity. Further studies are in progress to better characterize this infectious agent.

Other native Brazilian wild species may also be infected with hemotrophic mycoplasmas. Mycoplasma spp. detection in squirrel monkeys (Saimiri sciureus) in French Guiana, which borders Northern Brazil, raises the possibility of hemoplasma infection in native Brazilian monkeys (CONTAMIN et al., 1999; MICHEL et al., 2000; NEIMARK et al., 2002). Our research group is currently conducting a survey in Brazilian peccaries (T. pecari and T. tajacu) since $M$. suis infection was described in the USA (HANNON et al., 1985).

\section{Laboratory Animals}

Mycoplasma coccoides (formerly known as Eperythrozoon coccoides), which causes a mild hemolytic anemia in laboratory and wild mice, has been described in the blood smears of laboratory mice in Brazil (DE ANDRADE Jr et al., 1986). No further work has been published to date, and epidemiological, clinical and molecular characterization of $M$. coccoides in Brazil remains to be determined.

\section{Public Health}

Hemotrophic mycoplasmas infect a wide variety of mammals. There are also a few anecdotal reports of human infections. Recently, the first molecularly documented case of a human hemoplasma infection was found in Brazil, where a Mycoplasma haemofelis-like organism (Table 1) was detected in a HIV-positive patient co-infected with Bartonella henselae (SANTOS et al., 2008). Although this finding may represent an isolated case with no epidemiological consequence, it emphasizes the need for further research on the zoonotic potential of hemoplasma species.

\section{Conclusion}

In conclusion, hemoplasma species are common in the Brazilian cities where surveys were conducted. Further studies should be conducted in other regions. Also, studies should be conducted in which pathogenicity, host immune defense, disease transmission, and prevention of hemoplasmosis in non-human mammals, as well as the role of these animals as zoonotic agents, are concurrently addressed.

\section{References}

ADANIA, C. H. et al. Avaliação das condições veterinárias e de manejo dos pequenos felinos neotropicais em cativeiro do Estado de Sáo Paulo. Revista de Educaçáo Continuada do CRMV-SP, v. 1, n. 1, p. 44-54, 1998.

BATISTA, T. N. Frequência de infecçáo do Mycoplasma haemofelis e 'Candidatus Mycoplasma haemominutum' em gatos (Felis catus). Botucatu, 2004. 44f. Dissertação (Mestrado) - Universidade Estadual Paulista Júlio de Mesquita Filho. Disponível em: $<$ http://servicos.capes. gov.br/capesdw/resumo.html?idtese $=200436733004064022 \mathrm{P} 3>$.

BAUMANN, A. et al. Mycoplasma haemofelis and 'Candidatus Mycoplasma haemominutum' detection by PCR in anemic domestic cats (Felis catus) from Curitiba, Brazil: A Preliminary Study. Veterinary Clinical Pathology, v. 35, n. 3, p. 370, 2006.

BERKENKAMP, S. D.; WESCOTT, R. B. Arthropod transmission of Eperythrozoon coccoides in mice. Laboratory Animal Science, v. 38, n. 4, p. 398-401, 1988. 
CONTAMIN, H.; MICHEL, J. C. Haemobartonellosis in squirrel monkeys (Saimiri sciureus): antagonism between Haemobartonella sp. and experimental Plasmodium falciparum malaria. Experimental Parasitology, v. 91, n. 4, p. 297-305, 1999.

De ANDRADE Jr, H. F. et al. Malaria experimental: contaminação de cepas e animais de biotério por Eperythrozoon coccoides. Revista do Instituto de Medicina Tropical de Sáo Paulo, v. 28, n. 4, p. 246-252, 1986.

De MORAIS, H. S. A. et al. Mycoplasma haemocanis (previously Haemobartonella canis) in non-splenectomized dogs in Brazil: 4 cases (1999-2001). Journal of Veterinary Internal Medicine, v. 17, n. 3, p. $421,2003$.

De MORAIS, H. A. et al. Co-infection with Mycoplasma haemofelis and 'Candidatus Mycoplasma haemominutum' in three cats from Brazil. Journal of Feline Medicine and Surgery, v. 9, n. 6, p. 518-520, 2007.

GUIMARÁES, A. M. S. et al. Exploratory study of Mycoplasma suis (Eperythrozoon suis) on four commercial pig farms in Southern Brazil. Veterinary Record, v. 160, n. 3, p. 50-53, 2007a.

GUIMARÃES, A. M. S. Detecçáo de micoplasmas, bartonelas e vírus da leucemia felina em pequenos felídeos neotropicais mantidos em cativeiro no Refúgio Bela Vista, Foz do Iguaçu, 2008. São Paulo, 2008. 129f. Dissertaçáo (Mestrado) - Universidade de São Paulo.

HANNON, P. G. et al. Eperythrozoon in Captive Juvenile Collared Peccaries in Texas. Journal of Wildlife Diseases, v. 21, n. 4, p. 439-440, 1985.

HOELZLE, L. E. Haemotrophic mycoplasmas: recent advances in Mycoplasma suis. Veterinary Microbiology, v. 130, n. 3-4, p. 215-226, 2008.

HORA, A. S. Associaçáo da infecçáo por Mycoplasma haemofelis e os vírus da leucemia e imunodeficiência em felinos anêmicos. São Paulo, 2008. 115f. Dissertação (Mestrado) - Universidade de São Paulo.

MACIEIRA, D. B. et al. Hemoplasmas in domestic cats and possible assoassociation to feline immunodeficiency virus (FIV) and/or feline leukaemia virus (FELV) in naturally infected animals. Veterinary Clinical Pathology, v. 35, n. 3, p.368, 2006.

MACIEIRA, D. B. Hemoplasmas em gatos domésticos: prevalência e sua associaçáo à infecçáo natural pelos vírus das imunodeficiência e/ou leucemia felinas. Seropédica, 2008. 90f. Tese (Doutorado) Universidade Federal Rural do Rio de Janeiro.

MACIEIRA, D. B. et al. Prevalence and risk factors for hemoplasmas in domestic cats naturally infected with feline immunodeficiency vírus and/or feline leukemia vírus in Rio de Janeiro, Brazil. Journal of Feline Medicine and Surgery, v. 10, n. 2, p. 120-129, 2008.

MESSICK, J. B. Hemotrophic mycoplasmas (hemoplasmas): a review and new insights into pathogenic potential. Veterinary Clinical Pathology, v. 33, n. 1, p. 2-13, 2004.

MESSICK, J. B. et al. A novel haemoplasma in pigs. Veterinary Pathology, v. 44, n. 5, p. 769, 2007.

MICHEL, J. C.; de THOISY, B.; CONTAMIN, H. Chemotherapy of haemobartonellosis in squirrel monkeys (Saimiri sciureus). Journal of Medical Primatology, v. 29, n. 2, p. 85-87, 2000.

NEIMARK, H. et al. Proposal to transfer some members of the genera Haemobartonella and Eperythrozoon to the genus Mycoplasma with descriptions of 'Candidatus Mycoplasma haemofelis', 'Candidatus
Mycoplasma haemomuris', 'Candidatus Mycoplasma haemosuis' and 'Candidatus Mycoplasma wenyonii'. International Journal of Systematic and Evolutionary Microbiology, v. 51, p. 891-899, 2001.

NEIMARK, H. et al. The putative haemobartonella that influences Plasmodium falciparum parasitaemia in squirrel monkeys is a haemotrophic mycoplasma. Microbes Infection, v. 4, n. 7, p. 693-698, 2002.

NEIMARK, H.; HOFF, B.; GANTER, M. Mycoplasma ovis comb. nov. (formerly Eperythrozoon ovis), an eperythrocytic agent of haemolytic anaemia in sheep and goats. International Journal of Systematic and Evolutionary Microbiology, v. 54, p. 365-371, 2004.

NEIMARK, H. et al. Phylogenetic analysis and description of Eperythrozoon coccoides, proposal transfer to the genus Mycoplasma as Mycoplasma coccoides comb. nov. and request for an opinion. International Journal of Systematic and Evolutionary Microbiology, v. 55, p. 1385-1391, 2005.

O'DWYER, L. H.; GUIMARÃES, L.; MASSARD, C. L. Ocorrência de infecção múltipla por Babesia canis, Hepatozoon canis e Haemobartonella canis, em um cão esplenectomizado. Revista Brasileira de Ciência Veterinária, v. 4, n. 2, p. 83-84, 1997.

PRULlAGE, J. B.; WILLIAMS, R. E.; GAAFAR, S. M. On the transmissibility of Eperythrozoon suis by Stomoxys calcitrans and Aedes aegypti. Veterinary Parasitology, v. 50, n. 1-2, p. 125-135, 1993.

RIKIHISA, Y. et al. Western immunoblot analysis of Haemobartonella muris and comparison of $16 \mathrm{~S}$ rRNA gene sequences of $H$. muris, $H$. felis and Eperythrozoon suis. Journal of Clinical Microbiology, v. 35, n. 4, p. 823-829, 1997.

SANTOS, A. P. Infecçáo por hemoplasmas em felinos domésticos da regiáo de Porto Alegre, Rio Grande do Sul, Brasil. Porto Alegre, 2008. 162 f. Dissertaçáo (Doutorado) - Universidade Federal do Rio Grande do Sul.

SANTOS, A. P. et al. Hemoplasma Infection in HIV-positive Patient, Brazil. Emerging Infectious Diseases, v. 18, n. 12, p. 1922-1924, 2008.

SENEVIRATNA, P.; WEERASINGHE, N.; ARYIADASA, S. Transmission of Haemobartonella canis by the dog tick Rhipicephalus sanguineus. Research in Veterinary Science, v. 14, n. 1, p. 112-114, 1973.

SILVA, M. A. M. L. et al. Blood parasites, total plasma protein and packed cell volume of small wild mammals trapped in three mountain ranges of the Atlantic Forest in Southeastern Brazil. Brazilian Journal of Biology, v. 67, n. 3, p. 531-535, 2007.

SYKES, J. E. et al. 'Candidatus Mycoplasma haematoparvum', a novel hemotropic mycoplasma from a dog. International Journal of Systematic and Evolutionary Microbiology, v. 55, pt. 1, p. 27-30, 2005.

TAGAWA, M.; MATSUMOTO, K.; INOKUMA, H. Molecular detection of Mycoplasma wenyonii and 'Candidatus Mycoplasma haemobos' in cattle in Hokkaido, Japan. Veterinary Microbiology, v. 132, n. 1-2, p. 177-180, 2008.

TAMURA, K. et al. MEGA4: Molecular Evolutionary Genetics Analysis (MEGA) software version 4.0. Molecular Biology and Evolution, v. 24, n. 8, p. 1596-1599, 2007.

TRAPP, S. M.; MESSICK, J. B.; VIDOTTO, O.; JOJIMA, F. S.; DE MORAIS, H. S. A. Babesia gibsoni genotype Asia in dogs from Brazil. Veterinary Parasitology, v. 141, n. 1-2, p. 177-180, 2006. 
VIEIRA, R. F. C. et al. Detection of a novel hemoplasma based on $16 \mathrm{~S}$ rRNA gene DNA in captive and free-ranging capybaras (Hydrochaeris hydrochaeris). Veterinary Microbiology, 2009. (in press).

WEISS, E.; MOULDER, J. E. Order I: Rickettsiales. In: KRIEG, N. R.; HOLT, J. G. Bergey's manual of systematic bacteriology. Baltimore: Williams and Wilkins, 1984.
WILLI, B. et al. Worldwide occurrence of feline hemoplasma infections in wild felid species. Journal of Clinical Microbiology, v. 45, n. 4, p. 1159-1166, 2007.

WOODS, J. E. et al. Evaluation of experimental transmission of 'Candidatus Mycoplasma haemominutum' and Mycoplasma haemofelis by Ctenocephalides felis to cats. American Journal of Veterinary Research, v. 66, n. 6, p. 1008-1012, 2005. 